\title{
The metalloenzymic nature of collagenase-like peptidase of the rat testis
}

\author{
J. Lukač and E. Koren \\ Laboratory for Experimental Medicine, University of Zagreb, Domagojeva 2, \\ 41000 Zagreb, Yugoslavia
}

\begin{abstract}
Summary. Collagenase-like peptidase, an enzyme degrading synthetic collagenase substrate (PZ-pentapeptide), was purified from rat testes and its properties were examined. Its activity was strongly inhibited by chelating agents, such as EDTA and 1,10-phenanthroline. By chelation and exhaustive dialysis it was possible to obtain this enzyme in its inactive, metal-free form. The activity of the metal-free enzyme was partly recovered by treatment with zinc or manganese ions, while a combined zinc and manganese treatment resulted in complete recovery of enzyme activity.
\end{abstract}

\section{Introduction}

We have previously described a collagenase-like peptidase (CLP), an enzyme capable of degrading synthetic collagenase substrate, whose activity was detected in rat and bull testes and spermatozoa and in human spermatozoa (Koren \& Milković, 1973). While investigating the role of CLP in the male reproductive system we found that purified CLP from rat testes degraded proteins from the rat seminal vesicle secretion, and could thus promote the release of spermatozoa from the copulatory plug (Koren, Lukač \& Milković, 1974; Koren, Schön \& Lukač, 1975). CLP from human semen and testes participates in the liquefaction of the human ejaculate (Lukač, 1976).

Enzymes that can degrade synthetic collagenase substrate have been detected in a number of different animal tissues (Sakai et al. 1967; Strauch \& Vencelj, 1967; Cutroneo \& Fuller, 1970; Rabadjija, Koren \& Pende, 1971; Levdikova \& Orekovich, 1972; Aswanikumar \& Radhakrishnan, 1972,1973 ) and are believed to play some role in the degradation of extracellular proteins, although their properties have not been studied in detail. Woessner (1970) reported that such an enzyme, obtained from chick embryos, required $\mathrm{Ca}^{++}$for its activity, but no metal requirement was found for the enzyme from rat granuloma tissue (Aswanikumar \& Radhakrishnan, 1972). We therefore investigated whether the CLP isolated from rat testes requires metal cations for its activity.

\section{Materials and Methods}

\section{Chemicals}

Synthetic PZ-pentapeptide (4-phenylazo-benzyloxy-carbonyl-L-prolyl-L-leucyl-L-glycyl-L-prolylD-arginine) and PZ-dipeptide (4-phenylazo-benzyloxy-carbonyl-L-prolyl-L-leucin) were purchased from Fluka, Switzerland, $\mathrm{Na}_{2}$ EDTA from BDH, U.K., dithiothreitol and 2-mercaptoethanol from Sigma Chemicals Co., U.S.A., 1,10-phenanthrolin and cysteine from Merck, Germany. All the other chemicals were commercially available reagent-grade products.

\section{Purification of CLP from rat testes}

CLP was purified from rat testes by the acetone precipitation method described previously (Koren \& Milković, 1973). 
Preparation of the metal-free enzyme

CLP was dialysed in a small dialysing tube (A. H. Thomas Co., Philadelphia, U.S.A., $6 \mathrm{~mm}$ diam.) for $6 \mathrm{~h}$ against $500 \mathrm{ml} 20 \mathrm{~mm}$-EDTA. To remove EDTA the dialysis bag was then transferred to $500 \mathrm{ml}$ deionized water, $\mathrm{pH} \mathrm{7.5} \mathrm{(adjusted} \mathrm{by} \mathrm{tris).} \mathrm{Dialysis} \mathrm{was} \mathrm{continued} \mathrm{at} 4^{\circ} \mathrm{C}$ for $48 \mathrm{~h}$, with 6 changes of the outer solution, at constant magnetic stirring. To obtain the same ionic strength the control sample was prepared by dialysing CLP against deionized water.

\section{Enzyme assay}

The enzyme was assayed by the method of Wünsch \& Heidrich (1963) in a reaction mixture containing $100 \mu \mathrm{g}$ of enzyme preparation and $500 \mu \mathrm{g}$ PZ-pentapeptide in $2 \mathrm{ml} \mathrm{0.05} \mathrm{M}$-tris-acetic acid buffer, $\mathrm{pH} 7.5$, containing $0.05 \mathrm{M}-\mathrm{NaCl}$. After $60 \mathrm{~min}$ incubation at $37^{\circ} \mathrm{C}$ the reaction mixture was stopped with $0.5 \mathrm{ml} \mathrm{10 \%}$ citric acid, and the PZ-Pro-Leu released was extracted with $3 \mathrm{ml}$ ethyl acetate. Absorption was measured at $320 \mathrm{~nm}$.

The effects of various metal ions, chelators and sulphydryl compounds on CLP activity were tested after mixing $0.9 \mathrm{ml}$ enzyme solution with $0.1 \mathrm{ml}$ agent solution (dissolved in $0.05 \mathrm{M}$-tris-acetic acid buffer, $\mathrm{pH} 7 \cdot 5$ ).

In the assay of the metal-free CLP, all metal cation solutions and substrate solutions were prepared with deionized water, $\mathrm{pH} 7 \cdot 5$ (adjusted by tris).

In all experiments the degradation product was identified by thin-layer chromatography on Silica Gel G using the $n$-butanol:acetic acid:pyridine: water $(5: 1: 2 \cdot 2: 4$, by vol.) solvent system. PZ-pentapeptide and PZ-dipeptide were employed as standards.

The unit of enzyme activity was defined as the amount of enzyme releasing $1 \mu \mathrm{g}$ PZ-Pro-Leu under the above described conditions.

\section{Results}

Table 1 shows the effects of different bivalent cations on CLP activity. Heavy metals, such as $\mathrm{Zn}^{++}$, $\mathrm{Cu}^{++}, \mathrm{Ni}^{++}, \mathrm{Cd}^{++}$and $\mathrm{Hg}^{++}$, caused an almost complete inhibition of CLP activity in the concentration range of 0.1-1 mM. Magnesium ions showed no effect, while $\mathrm{Ca}^{++}$and $\mathrm{Mn}^{++}$stimulated CLP activity.

Chelating agents also caused inhibition of CLP activity (Table 1), the most effective inhibitor being 1,10-phenanthroline (1 mM).

At the concentrations tested (Table 1) the sulphydryl compounds had no effect on CLP activity, but after inhibition with $\mathrm{Hg}^{++}$cysteine and dithiothreitol elicited recovery of enzyme activity (Table 2). Following inhibition with EDTA attempts were made to restore the enzyme activity with various metallic cations (Table 3), but even a five-fold excess of ions was ineffective.

After exhaustive dialysis against EDTA the enzyme remained almost completely inhibited, while the activity of the control CLP preparation (dialysed against deionized water only) underwent practically no change (Table 4).

As shown in Table 5 the activity of the CLP inactivated by dialysis against EDTA could be partly restored by $\mathrm{Zn}^{++}$ions. A zinc ion concentration of $1 \mu \mathrm{M}$ restored about $40 \%$ of the enzyme activity, while higher concentrations caused an inhibitory effect. Almost complete restoration of CLP activity was achieved only by the combined action of zinc and manganese ions (Table 5).

\section{Discussion}

These results show that heavy metals have a strong inhibitory effect on the activity of CLP from rat testis. The fact that inhibition by $\mathrm{Hg}^{++}$can be effectively reversed by sulphydryl compounds such as cysteine and dithiothreitol (Table 2) seems to indicate that sulphydryl groups are required for the 
Table 1. The effect of some metallic cations, chelating agents and $\mathrm{SH}$ agents on the activity of collagenase-like peptidase from rat testis

\begin{tabular}{|c|c|c|c|}
\hline & $\mathrm{mM}$ & $\begin{array}{c}\% \text { of } \\
\text { activity }\end{array}$ & $\begin{array}{c}\text { No. of } \\
\text { estimations }\end{array}$ \\
\hline \multicolumn{4}{|l|}{ Cations* } \\
\hline None & - & 100 & 12 \\
\hline \multirow[t]{2}{*}{$\mathrm{Zn}^{++}$} & $0 \cdot 1$ & 7 & 7 \\
\hline & 1 & 5 & 7 \\
\hline \multirow[t]{2}{*}{$\mathrm{Cu}^{++}$} & $0 \cdot 1$ & 5 & 4 \\
\hline & 1 & 0 & 4 \\
\hline \multirow[t]{2}{*}{$\mathrm{Cd}^{++}$} & 0.1 & 0 & 3 \\
\hline & 1 & 0 & 3 \\
\hline \multirow[t]{2}{*}{$\mathrm{Ni}^{++}$} & 0.1 & 0 & 3 \\
\hline & 1 & 0 & 3 \\
\hline $\mathrm{Hg}^{++}$ & 0.1 & 10 & 3 \\
\hline \multirow[t]{2}{*}{$\mathrm{Mg}^{++}$} & $0 \cdot 1$ & 100 & 3 \\
\hline & 1 & 100 & 3 \\
\hline \multirow[t]{5}{*}{$\mathrm{Ca}^{++}$} & 0.1 & 100 & 7 \\
\hline & 1 & 125 & 9 \\
\hline & 5 & 142 & 9 \\
\hline & 10 & 131 & 9 \\
\hline & 50 & 122 & 6 \\
\hline \multirow[t]{5}{*}{$\mathrm{Mn}^{++}$} & 0.1 & 127 & 3 \\
\hline & 1 & 132 & 4 \\
\hline & 5 & 149 & 4 \\
\hline & 10 & 167 & 6 \\
\hline & 50 & 159 & 4 \\
\hline \multicolumn{4}{|l|}{ Chelating agents $\dagger$} \\
\hline None & - & 100 & 11 \\
\hline \multirow[t]{4}{*}{$\mathrm{Na}_{2}$ EDTA } & 1 & 74 & 4 \\
\hline & 5 & 49 & 8 \\
\hline & 10 & 36 & 8 \\
\hline & 20 & 11 & 4 \\
\hline \multirow[t]{2}{*}{ 1,10-Phenanthroline } & 0.1 & 39 & 5 \\
\hline & 1 & 28 & 9 \\
\hline \multicolumn{4}{|l|}{ SH agentst } \\
\hline Dithiothreitol & 10 & 100 & 4 \\
\hline Dimercaptoethanol & 10 & 100 & 4 \\
\hline Cysteine & 10 & 100 & 4 \\
\hline
\end{tabular}

* In the chloride form.

† The incubation mixture contained $10 \mathrm{~mm}-\mathrm{CaCl}_{2}$.

activity of this enzyme. The inhibitory effect of the chelating agents is most probably due to the binding of the heavy metal. This interpretation can be supported by several pieces of indirect evidence: (a) 1,10-phenanthroline, which has a poor binding affinity to calcium and a markedly strong affinity to heavy metals (Sillèn \& Martel, 1964), is effective in low concentrations; (b) phenanthroline also has an inhibitory effect when there is a great excess of $\mathrm{Ca}$ ions; (c) after inhibition by EDTA, which

Table 2. Restoration of collagenase-like peptidase activity by SH agents after inhibition by $\mathbf{H g}^{++}$

\begin{tabular}{lcc}
\hline \multicolumn{1}{c}{ Addition } & $\begin{array}{c}\% \text { of } \\
\text { activity }\end{array}$ & $\begin{array}{c}\text { No. of } \\
\text { estimations }\end{array}$ \\
\hline None & 100 & 4 \\
$0 \cdot 1 \mathrm{~mm}-\mathrm{Hg}^{++}$ & 10 & 4 \\
$0 \cdot 1 \mathrm{~mm}-\mathrm{Hg}^{++}+1 \mathrm{~mm}$-cysteine & 92 & 4 \\
$0 \cdot 1 \mathrm{~mm}-\mathrm{Hg}^{++}+1 \mathrm{~mm}$-dithiothreitol & 50 & 4 \\
\hline
\end{tabular}


Table 3. Reversal of $\mathrm{Na}_{2}$ EDTA inhibition of collagenase-like peptidase activity by some metallic cations

\begin{tabular}{cccc}
\hline $\begin{array}{c}\mathrm{Na}_{2} \text { EDTA added } \\
(\mathrm{mM})\end{array}$ & $\begin{array}{c}\text { Cation added } \\
\text { (mM) }\end{array}$ & $\begin{array}{c}\% \text { of } \\
\text { activity }\end{array}$ & $\begin{array}{c}\text { No. of } \\
\text { estimations }\end{array}$ \\
\hline- & - & 100 & 5 \\
5 & - & 29 & 5 \\
5 & $\mathrm{Ca}^{++} 5$ & 32 & 5 \\
5 & 10 & 36 & 5 \\
5 & 25 & 37 & 5 \\
5 & $\mathrm{Mn}^{++} 5$ & 30 & 5 \\
5 & 10 & 30 & 5 \\
5 & 25 & 27 & 5 \\
5 & $\mathrm{Zn}^{++} 5$ & 20 & 3 \\
5 & 10 & 0 & 3 \\
\hline
\end{tabular}

Table 4. The effect of $\mathrm{Na}_{2}$ EDTA inhibition $(20 \mathrm{mM})$ and dialysis against deionized water on collagenase-like peptidase (CLP) activity

\begin{tabular}{lcc}
\hline \multicolumn{1}{c}{ Treatment } & $\begin{array}{c}\text { Activity* } \\
\text { ( } \mu \mathrm{g} \text { PZ-dipeptide/ } \\
\text { ml incubation mixture) }\end{array}$ & $\begin{array}{c}\% \text { of } \\
\text { activity }\end{array}$ \\
\hline Uninhibited, undialysed CLP & $32 \cdot 0 \pm 2 \cdot 61^{*}$ & 100 \\
Uninhibited, dialysed CLP & $26 \cdot 6 \pm 3 \cdot 13$ & 83 \\
Inhibited, dialysed CLP & $3 \cdot 8 \pm 0 \cdot 42$ & 12 \\
\hline
\end{tabular}

* Mean \pm S.E.M. of 5 estimations.

Table 5. The effect of zinc and manganese ions on the activity of collagenase-like peptidase inactivated by chelation and exhaustive dialysis

\begin{tabular}{ccc}
\hline $\mathrm{Zn}^{++}(\mathrm{M})$ & $\mathrm{Mn}^{++}(\mathrm{M})$ & $\%$ of activity* \\
\hline- & - & 12 \\
$10^{-7}$ & - & 15 \\
$10^{-6}$ & - & 41 \\
$10^{-5}$ & - & 24 \\
$10^{-6}$ & $10^{-5}$ & 41 \\
$10^{-6}$ & $10^{-4}$ & 60 \\
$10^{-6}$ & $10^{-3}$ & 81 \\
$10^{-6}$ & $10^{-2}$ & 80
\end{tabular}

Each number represents the mean values of 5 estimations.

* $100 \%$ activity is that of uninhibited, undialysed CLP (Table 4).

also prefers heavy metal ions, the enzyme activity cannot be reversed even with a great excess of $\mathrm{Ca}^{++}$ or $\mathrm{Mn}^{++}$(Table 3); (d) following dialysis against EDTA, the enzyme activity can be partly restored only by $\mathrm{Zn}^{++}$, while $\mathrm{Ca}^{++}$or $\mathrm{Mn}^{++}$alone remain ineffective.

It appears that a heavy metal is firmly bound to the enzyme molecule, since CLP activity cannot be diminished by dialysis against deionized water alone, and because the inactive enzyme could be obtained only by dialysis against EDTA (Table 4). The results (Table 5) indicate that complete CLP activity requires two metals: one, most probably $\mathrm{Zn}^{++}$, for its catalytic function, and another $\left(\mathrm{Ca}^{++}\right.$ or $\mathrm{Mn}^{++}$) for the stabilization of the enzyme molecule.

The effect of $\mathrm{Ca}^{++}$on collagenases has been described in connection with bacterial and animal collagenases. In the case of human and rat skin and uterus collagenase (Seltzer, Welgus, Jeffrey \& 
Eisen, 1973), $\mathrm{Ca}^{++}$is necessary for thermostabilization, while in clostridial collagenase $\mathrm{A}$ it appears to participate in the binding of the enzyme to the substrate (Seifter \& Harper, 1970). In addition to their requirement for extrinsic $\mathrm{Ca}^{++}$, some collagenases appear to contain an intrinsic metal ion. Clostridial collagenase A is known to contain $\mathrm{Zn}^{++}$(Seifter \& Harper, 1970), and the same metal is most probably present also in some animal collagenases (Berman \& Manabe, 1973). Although CLP can not be considered a 'true collagenase' (it does not degrade native collagen), it is obviously similar to collagenases, not only because it is capable of degrading a synthetic collagenase substrate and collagen peptides (Koren \& Milković, 1973), but also in respect to its metal requirement. The fact that zinc is one of the metals inhibiting CLP activity (Table 1) does not exclude the possibility that this metal is present at the active site of the enzyme, since it is known that a metal present at the active centre of an enzyme molecule may exert an inhibitory effect when it is also bound to some other part of the same molecule (Vallee, 1960).

The results obtained indicate that CLP from rat testes is a true metalloenzyme with a tightly bound intrinsic metal necessary for its activity.

This work was supported in part by research grant No. 720-044 from the Ford Foundation, New York, and grant No. IV/3 from the Croatian Republican Research Fund.

\section{References}

Aswanikumar, S. \& Radhakrishnan, A.N. (1972) Purification and properties of a peptidase acting on a synthetic collagenase substrate from experimental granuloma tissue in the rat. Biochim. biophys. Acta 276, 241-249.

Aswanikumar, S. \& Radhakrishnan, A.N. (1973) Studies on a peptidase active on synthetic collagenase substrate. Developmental pattern in rat granuloma tissue and distribution of enzyme in the tissue of various animals. Biochim. biophys. Acta 230, $620-626$.

Berman, M.B. \& Manabe, A.R. (1973) Corneal collagenases: evidence for zinc metalloenzymes. Ann. Ophthal. 5, 1193-1209.

Cutroneo, K.R. \& Fuller, G.C. (1970) Application of a rapid colorimetric assay to detect alterations in rat proline iminopeptidase. Biochim. biophys. Acta 198, 271-275.

Koren, E. \& Milković, S. (1973) "Collagenase-like" peptidase in human, rat and bull spermatozoa. $J$. Reprod. Fert. 32, 349-356.

Koren, E., Lukač, J. \& Milković, S. (1974) The effect of collagenase-like peptidase from rat testis and clostridial collagenase $A$ on the rat seminal vesicle secretion and its coagulation. $J$. Reprod. Fert. 36, 161-167.

Koren, E., Schön, E. \& Lukač, J. (1975) The coagulation of insoluble and basic proteins from rat seminal vesicle secretion with vesiculase: influence of collagenase-like peptidase from rat testis. $J$. Reprod. Fert. 42, 491-495.

Levdikova, G.A. \& Orekovich, B.N. (1972) On a collagenase-like enzyme detected in the extracts of hypothalamus and hypophysis. Clin. Chim. Acta 42 , 205-208.

LuKAC, J. (1976) Liquefaction of human ejaculate: its mechanism and significance. Ph.D. thesis, Faculty of Pharmacy and Biochemistry, University of Zagreb, Yugoslavia.

Rabadjija, L., Koren, E. \& Pende, B. (1971) Studies on the composition of extracellular fluid from calf costal cartilage. Biochim. biophys. Acta 230, 620-626.

Sakai, T., Oda, T., Yokono, Y., Igarashi, S., Suzuki, H. \& Joshitoshi, Y. (1967) Collagenase-like peptidase activity in fibrotic liver tissue. Clin. chim. Acta 15, 321-324.

SeIfTer, S. \& HARPER, E. (1970) Collagenases. In Methods in Enzymology, Vol. XIX, pp. 613-635. Eds S. P. Collowick \& N. O. Kaplan. Academic Press, New York.

Seltzer, J.L., Welgus, H.G., JefFrey, J.J. \& Eisen, A.Z. (1973) The function of $\mathrm{Ca}^{++}$in the action of mammalian collagenases. Archs Biochem. Biophys. 173, 355-361.

Sillèn, L.S. \& MARTEL, A.E. (1964) Stability Constants of Metal-Ion Complexes, p. 665. The Chemical Society, Burlington House, London.

Strauch, L. \& VencelJ, H. (1967) Collagenases in mammalian cells. Hoppe-Seyler's Z. physiol. Chem. $348,465-468$.

VALLEE, B.L. (1960) Metal and enzyme interactions: correlation of composition, function and structure. In The Enzymes, Vol. 3, pp. 225-276. Eds P. D. Boyer, H. Lardy \& K. Myrrbäck. Academic Press, New York.

WOESSNER, J.F., JR (1970) Collagen remodelling in chick skin embryogenesis. In Chemistry and Molecular Biology of the Intercellular Matrix, Vol. 3, pp. 16631669. Ed. E. A. Balazs. Academic Press, London.

WüNSCH, E. \& HeIdRICH, H.G. (1963) Zur quantitativen Bestimmung der Kollagenase. Hoppe-Seyler's $Z$. physiol. Chem. 33, 149-155. 